\title{
Urethral dysontogenic metaplasia in cat with bilateral renal dysplasia
}

\section{Metaplasia disontogênica uretral em um felino com displasia renal bilateral}

\author{
Carolina da Fonseca Sapin ${ }^{1}$; Luisa Mariano Cerqueira da Silva ${ }^{1}$; \\ Haide Valeska Scheid ${ }^{2}$; Ceres Cristina Tempel Nakasu²; Marlete Brum Cleff ; \\ Fabiane Borelli Grecco ${ }^{4 *}$
}

\begin{abstract}
This paper to describe a case of dysontogenic urethral metaplasia in a one month old mongrel feline who also had bilateral renal dysplasia. Dysontogenic metaplasia in cats are scarce and this change may be associated with renal dysplasia and/or lower urinary tract. The animal had history of abdominal enlargement since birth and dysuria, eliminating urine only dropwise. Due to the poor prognosis we opted for euthanasia. At necropsy was observed enlarged and distended bladder, reduced kidneys and dilated and tortuous ureters. The urethra was thickened, hard to cut, and histologically, was replacing the connective tissue, cartilage and endochondral ossification areas, which features dysontogenic metaplasia. Both kidneys presented primitive appearance featuring dysplasia. Dysontogenic metaplasia in urinary tract feline with renal dysplasia, has not been described.
\end{abstract}

Key words: Congenital disease. Malformation. Nephropathy.

\section{Resumo}

Este trabalho tem como objetivo descrever um caso de metaplasia disontogênica uretral em um felino sem raça definida de um mês de idade, que também apresentava displasia renal bilateral. Dados sobre metaplasia disontogênica em felinos são escassos e a alteração pode estar associada a displasia renal e/ ou do trato urinário inferior. $\mathrm{O}$ animal apresentava histórico de aumento abdominal desde o nascimento e disúria, eliminando a urina apenas por gotejamento. Devido ao prognóstico desfavorável optou-se pela eutanásia. Na necropsia observou-se bexiga aumentada e dilatada, rins diminuídos e ureteres dilatados e tortuosos. A uretra apresentava-se espessada e firme ao corte, e histologicamente, havia substituição ao tecido conjuntivo, áreas de cartilagem e zonas de ossificação endocondral, o que caracteriza metaplasia disontogênica. Ambos os rins apresentavam aspecto primitivo caracterizando a displasia renal. A metaplasia disontogênica no trato urinário de felinos com displasia renal, não tem sido descrita.

Palavras-chave: Doença congênita. Malformação. Nefropatia.

1 Discentes de Doutorado, Universidade Federal de Pelotas, UFPel, Pelotas, RS, Brasil. E-mail: carolinasapin@yahoo.com.br; luisamarianovet@yahoo.com.br

2 Discentes de Mestrado, UFPel, Pelotas, RS, Brasil. E-mail: haidevaleskasheid@hotmail.com; ceresnakasu@hotmail.com

3 Prof a Adjunta, UFPel, Pelotas, RS, Brasil. E-mail: marletecleff@gmail.com

4 Prof.a Adjunta, UFPel, Pelotas, RS, Brasil. E-mail: fabianegrecco18@gmail.com

* Author for correspondence 


\section{Introduction}

Congenital urinary tract diseases in felines are infrequent (LEES, 1996; BUOTE; REESE, 2006). Dysontogenic metaplasia consists of persistent cartilaginous or osseous tissue, being characterized by unusual congenital abnormalities. These signs are observed in dysplastic kidneys of humans and domestic animals (CIANCIOLO; MOHR, 2015) but not in felines. There are reports of amyloidosis in Abyssinian felines, polycystic kidneys in Persians (CIANCIOLO; MOHR, 2015), infantile polycystic kidneys in Persian mestizos (LEES, 1996), unilateral renal dysplasia in non-breed felines (AZIZI et al., 2010), and juvenile bilateral renal dysplasia in Norwegian Forest cats (ARESU et al., 2009).

Renal dysplasia, rarely reported in cats (ARESU et al., 2009), is a structural disorganization resulting from abnormal differentiation and presence of abnormal structures in nephrogenesis of hereditary or acquired origin (PICUTT; LEWIS, 1987; LEES, 1996; OHARA et al., 2001; CIANCIOLO; MOHR, 2015). Usually, these abnormalities are congenital, but in felines, canines, and pigs with a nephrogenic zone active at birth, dysplasia can be caused by diseases in the neonatal period where tissue differentiation is complete (CIANCIOLO; MOHR, 2015). Dysplastic kidneys are morphologically and clinically similar to those of elderly animals with chronic nephropathy. The diagnosis of this disease is based on histological criteria (CIANCIOLO; MOHR, 2015), such as the presence of metanephric ducts, immature mesenchyme persistence, atypical tubular epithelium, and dysontogenic metaplasia (PICUTT; LEWIS, 1987; SCHULZE et al., 1998).

This study aimed to describe a case of urethral dysontogenic metaplasia and urinary tract dysplasia of congenital origin in a young feline, diagnosed in the Department of Animal Pathology of the College of Veterinary Medicine (FV), Federal University of Pelotas (UFPel), Brazil.

\section{Case Report}

A one-month-old non-breed female feline from a litter of 10 animals was treated at the Veterinary Clinic Hospital of the FV/UFPel. The feline was in shock, and venous access was not possible. A history of increased abdominal cavity volume was observed since birth. The animal also had difficulty urinating, eliminating the urine only by cystocentesis, bladder catheterization, or drip, being removed at a first moment $300 \mathrm{~mL}$ of urine by cystocentesis. None of the other animals in the litter showed any clinical signs or alterations. Ultrasound examination revealed a full bladder. Due to this unfavorable prognosis, the euthanasia was chosen by using intravenous barbiturates as recommended by the ethics code of the Federal Council of Veterinary Medicine and subsequently the animal was sent to necropsy.

At the post-mortem examination, the bladder was markedly distended, filled with urine, and occupied 3/4 of the abdominal cavity. There was an asymmetry of the kidneys, which were diminished in size, and in the longitudinal cross-sectional view both had a poorly evident cortical-medullar delimitation. Ureters were proportionally short, tortuous, and dilated. Microscopically, kidneys presented persistence of primitive mesenchyme, which was evidenced by the Masson's trichrome stain, in addition to an asynchronous differentiation of the nephrons, persistence of metanephric ducts, and atypical tubular epithelium (FIGURE 1B). The renal capsule was thickened, with multilocular adipose tissue and calcium deposit at the cranial pole. In the urethra, we observed areas of cartilage and zones of endochondral ossification in the connective tissue, which characterizes dysontogenic metaplasia (Figure 1C), which, in its turn, obstructed the urinary flow.

The clinical signs and lesions found in this case were indicative of renal failure. This is a common consequence of kidney diseases in older animals and can be caused by various disorders 
including interstitial nephritis, glomerulonephritis, and pyelonephritis. However, in young animals, renal failure occurs less frequently, being usually associated with hereditary causes (PICUTT; LEWIS, 1987; LESS, 1996; CIANCIOLO; MOHR, 2015).

Figure 1. Urethral dysontogenic metaplasia in a feline with bilateral renal dysplasia. A) Urinary tract dysplasia of the feline; bladder distension, hydroureter, and decreased kidneys; B) Renal dysplasia - renal parenchyma characterized by immature tubules and glomeruli (arrow); C) Substitution of connective tissue by cartilaginous and osseous tissue, characterizing the urethral dysontogenic metaplasia.

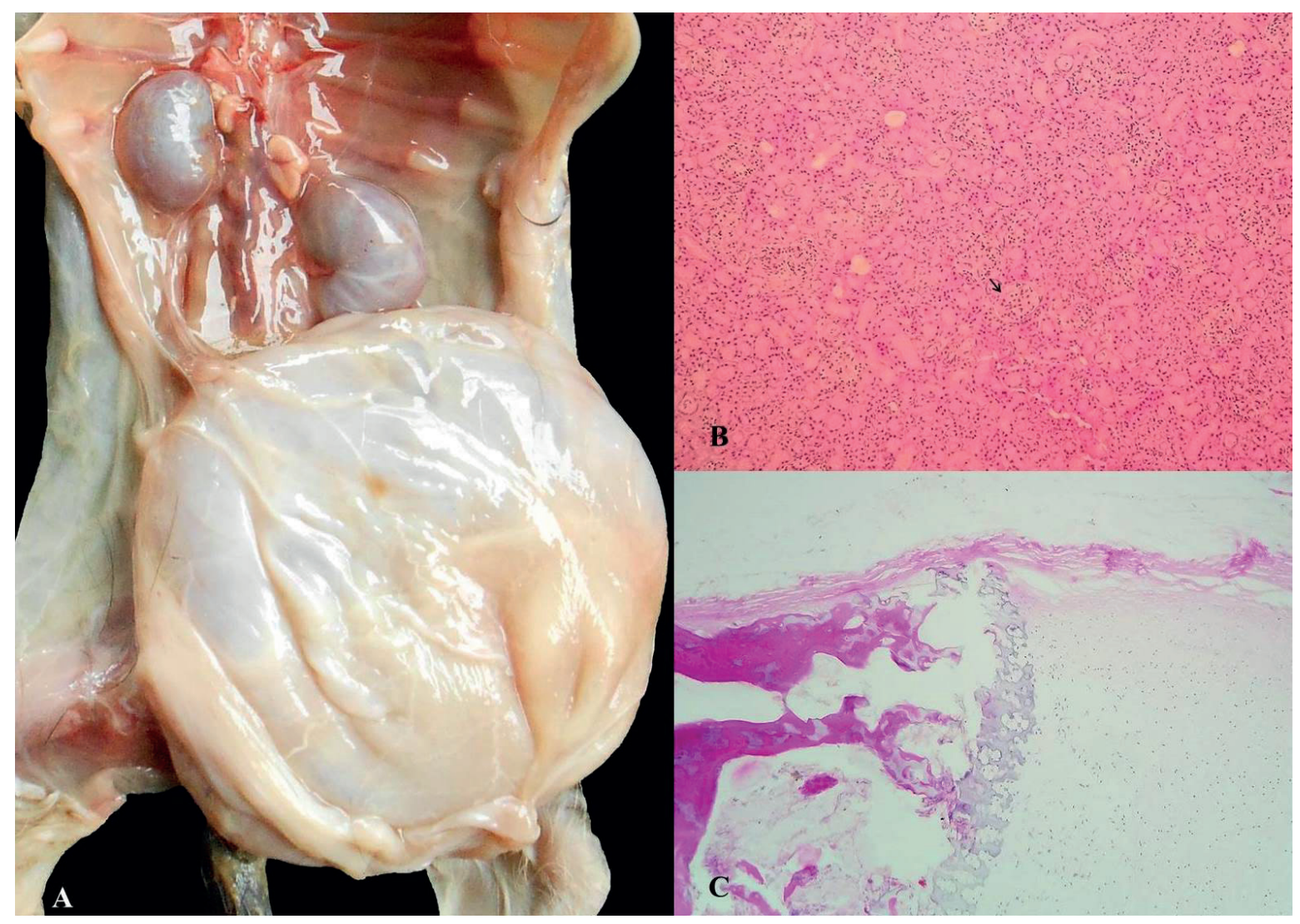

Congenital diseases of felines in the urinary tract are rare (LEES, 1996; BUOTE; REESE, 2006). In this report, the animal presented congenital renal and urethral lesions, which led to the feline's clinical condition. Hereditary nephropathies in animals may be subdivided into agenesis, hypoplasia, dysplasia, primary cystic disease, glomerulopathy, and tubulointerstitial diseases (PICUTT; LEWIS, 1987). Known causes of acquired anomalies in veterinary medicine include teratogenic infectious agents such as feline panleukopenia virus, toxic plants, chemical substances, or nutritional deficiencies. Malformations can still occur without a specific cause (MARTINI-SANTOS et al., 2012). In our report, we could determine if the alteration were of hereditary or acquired origin due to the lack of knowledge of maternal clinical history, epidemiology, and clinical and neonatal exams. A genetic implication could be suggested as the etiology since only one young animal, among the ten in the litter, was affected. On the other hand, felines infected by a transplacental virus, or in the 
neonatal phase, may develop abnormalities of organ differentiation such as cerebellum or other tissues still in the maturation stage (CIANCIOLO; MOHR, 2015). However, metaplasia alterations such as those found in this study, hypothesized, would not develop in 30 days, the feline's age in this report.

Macroscopic alteration4s of the affected kidneys, in this case, are among those described for renal dysplasia, although small and irregular kidneys in young animals are often misdiagnosed as hypoplastic. Therefore, observation of small kidneys in puppies of dogs and cats should have a differential diagnosis of renal hypoplasia, renal fibrosis, renal dysplasia, and progressive juvenile nephropathy of some breeds of dogs (CIANCIOLO; MOHR, 2015).

In this study, we observed important bladder and urethra lesions being determinant for the severity of the animal's clinical condition. The described dysontogenic metaplasia involved the urethra and not the kidneys, besides not being reported in dogs or cats. Dysontogenic metaplasia (cartilaginous or osseous) is reported in some dysplastic kidneys of humans and may rarely be present in dysplastic kidneys of domestic animals. This absence is related to the development stage of the kidneys at the time of lesion, which is different among species (CIANCIOLO; MOHR, 2015).

Microscopic renal alterations found in this report are within the five criteria for dysplasia classification: 1) asynchronous differentiation of nephrons; 2) persistence of primitive mesenchyme; 3) persistence of metanephric ducts; 4) atypical tubular epithelium and presence of cartilaginous or osseous tissue (CIANCIOLO; MOHR, 2015), although no cartilaginous or osseous metaplasia was found in the kidneys. Studies related to renal dysplasia in felines do not describe cartilaginous or osseous metaplasia in the urinary tract (ARESU et al., 2009; AZIZI et al., 2010), which highlights the importance of the alterations described here.

\section{References}

ARESU, L.; ZANATTA, R.; PREGEL, P.; CALIARI, D.; TURSI, M.; VALENZA, F.; TARDUCCI, A. Bilateral juvenile renal dysplasia in a Norwegian Forest Cat. Journal of Feline Medicine and Surgery, Chicago, v. 11, n. 4, p. 326-329, 2009.

AZIZI, S.; KHEIRANDISH, R.; YAZDANPOUR, H. Histopathologic features of a unilateral renal dysplasia in a cat. Comparative Clinical Pathology, Londres, v. 19, n. 5, p. 445-447, 2010.

BUOTE, N. J.; REESE, C. J. Congenital tarsal hyperextension in three cats. Journal of the American Veterinary Medical Association, Schaumburg, v. 228, n. 6, p. 1200-1203, 2006.

CIANCIOLO, R. F.; MOHR, F. C. Urinary system. In: JUBB, K. P. Pathology of domestic animals. $6^{\text {th }}$ ed. St. Louis: Elsevier Limited, 2015. v. 2, cap. 4, p. 376-464.

LEES, G. E. Congenital renal diseases. Veterinary Clinics of North America: Small Animal Practice, Philadelphia, v. 26, n. 6, p. 1379-1393, 1996.

MARTINI-SANTOS, B. J.; DIEFENBACH, A.; PEIXOTO, T. C.; NÓBREGA, J. E.; ANJOS, B. L. Anomalias congênitas múltiplas em felinos domésticos neonatos. Acta Scientiae Veterinariae, Porto Alegre, v. 40, n. 4, p. 1-6, 2012.

OHARA, K.; KOBAYASHI, Y.; TSUCHIYA, N.; FURUOKA, H.; MATSUI, T. Dysplasia renal in a Shih Tzu dog in Japan. The Journal of Veterinary Medical Science, Tokyo, v. 63, n. 10, p. 1127-1130, 2001.

PICUTT, C. A.; LEWIS, R. M. Microscopic features of canine renal dysplasia. Veterinary Pathology, Guelph, v. 24, n. 2, p. 156-163, 1987.

SCHULZE, C.; MEYER, H. P.; BLOK, A. L.; SCHIPPER, K.; VAN DEN INGH, T. S. G. A. M. Renal dysplasia in three young adult dutch kooiker dogs. The Veterinary Quarterly, Bern, v. 20, n. 4, p. 146-148, 1998. 